[This is the accepted version of an article that was published in Review of International Studies, vol. 44, no. 5, pp. 902-921. For the published version, see

https://doi.org/10.1017/S0260210518000311.]

\title{
Misrecognition and the Indian State: The Desire for Sovereign Agency
}

\section{Authors:}

Catarina Kinnvall and Ted Svensson

\begin{abstract}
A focus on misrecognition allows us to move between levels of analysis in a holistic fashion. If misrecognition works through the conscious and the unconscious we can account for the many overlapping insecurities and securities believed to exist at the individual, group or state level - and thus felt. These insecurities also present themselves through the categories used to describe them and the policies through which they become materialised, technologised and depoliticised, often by closing down discursive boundaries. Lacan's concepts of desire, real and lack are here important for understanding the impossibility of recognising something that cannot be recognised. Hence, a perspective that takes misrecognition not as an end result or as failed attempts to reformulate the exceptional as the normal, has the potential to rethink the political subject. In empirical terms, the article discusses how this process of misrecognition has been shaped in the Indian context of postcolonial state formation and articulations of sovereignty. We show how the Indian state is being rethought, restructured and reimagined through Hindu nationalism and how the concept of misrecognition accounts for desires for sovereign agency and group cohesiveness, but also for resistance to various re-imaginations of the Indian state.
\end{abstract}

\section{Keywords:}

misrecognition, sovereignty, security, psychoanalysis, India 


\section{Introduction}

In this article, we proceed from the description provided in the introduction to this special issue regarding Hegel's concept of misrecognition to discuss in detail how a closer reading of Lacanian and postcolonial analysis can develop this concept. Hegel's understanding of recognition emerges from its own impossibility - the paradox of recognition dynamics as both driving politicised behaviour and being impossible to achieve. This implies that misrecognition, rather than recognition is the norm. The editors of the special issue suggest that we start from the impossibility of recognition to advance our thinking about the ways in which the desire for recognition shapes the international system. As they put it, 'the international system is defined by a symbolic structure organised around an always unrealisable ideal of sovereign agency'; an 'ideal that operates at all levels of analysis'. ${ }^{1}$

Lacan's concepts of desire, the real, mirror images and lack are here important for understanding the impossibility of arriving at a stage or state of attained and fully achieved recognition, both on the level of the self and in terms of mutual recognition. Especially in those instances, such as postcolonial India, where the desire for 'collective political agency' takes the form of a most violent suppression of 'the structural impossibility of actors being recognised in the ways they want to be'. ${ }^{2}$ Provided this, how do unfulfilled desires, as discussed in Epstein's contribution to this special issue, ${ }^{3}$ shape state making and the international system, what are included in such desires, and how do they manifest themselves in the case of India? Also, if

\footnotetext{
${ }^{1}$ See Charlotte Epstein, Thomas Lindemann and Ole Jacob Sending, this issue.

${ }^{2}$ Epstein, Lindemann and Sending (this issue). Recent tendencies to equate India with a Hindu state clearly sits at the intersection of what Ayse Zarakol (this issue) describes as the 'dual task' of the modern state, i.e. 'providing sovereignty for its citizens while also being sovereign over its citizens'. The fantasy of India as a Hindu state as we fully explore below - 'reveals', to speak with Epstein (this issue), the 'compensatory structure whereby political actors $[\ldots]$ are always chasing after what they do not have', and which they cannot obtain.

${ }^{3}$ Charlotte Epstein, this issue.
} 
misrecognition is shaped by indeterminacy and incompletion, as argued below, how can we conceive of resistance and change?

To address these questions, we need to take a step back and consider the implicit assumptions behind much work in IR on recognition and the particular notion of subjectivity that underlies such assumptions. Hence, whether we are content with the possibility of recognition even when difficult to assess (as much work on thin and thick recognition seems to be) ${ }^{4}$ or believe, in line with Hegel's work on the negative, that such recognition can never fully occur, and thus that misrecognition will always prevail, we need to have a clearer understanding of how subjectivity is conceived in the first place and the extent to which 'affective recognition' or 'affective misrecognition' among collectives and states can be extrapolated from the individual. In this, a critical reading of recognition demands a serious interrogation of 'the traditional discourse of philosophy as ontology, the discourse of "being," that validates "presence" only, be it past, present, or future "presence," and thereby refuses to acknowledge the specters that always haunt it'. ${ }^{5}$ Such a critical reading thus needs to interrogate how notions of the past, present and future are built into the symbolic structures of the international system in ways that privilege the telling of a foundational story of subjectivity that, although desirable, remains always both allusive and evasive.

Contrary to a view that would contend that sovereignty, on the face of it, seems to work quite well and provides a workable and stable anchoring of politics and agency in the international realm, we concur with what the authors of the introduction to this special issue maintain

\footnotetext{
${ }^{4}$ See, for example, Hans Agné, 'The politics of international recognition: symposium introduction', International Theory, 5:1 (2013), pp. 94-176; Karl Gustafsson, 'Recognising recognition through thick and thin: insights from Sino-Japanese relations', Cooperation and Conflict, 52:1 (2016), pp. 255-271.

${ }^{5}$ Elisabeth Weber, 'Ages of cruelty: Jacques Derrida, Fethi Benslama, and their challenges to psychoanalysis', Mosaic, 48:2 (2015), pp. 1-15.
} 
regarding the primacy of misrecognition, namely that (1) recognition entails misrecognition, and vice versa; (2) self-consciousness and thereby subject-formation revolves around an always unfulfilled desire, which make contingent those things that IR tends to reify and essentialise; and (3) agency - to echo Hegel through Pippin ${ }^{6}-$ is best conceived of as 'a practical achievement', one which is 'inherently social'.

As noted in the special issue introduction, and as explicated by Epstein (this issue), Honneth's model of social conflict has stirred up a great deal of interest and debate, with the positioning of affect being one of its attractive elements (mainly because it counters the hyper-rationalism of much social theory), as well as a source of contention. We will not reiterate the debate here, but only reframe some of the contentions between the relational approach suggested by Honneth and critiqued by Fraser and McNay (among others) and that of Lacanian and postcolonial psychoanalysis to more thoroughly delineate what is at stake in terms of the particular notion of subjectivity that informs much work on recognition and the desire for sovereign agency. The first section outlines some of the contentions involved in the debate between relational psychology and Lacanian psychoanalysis to discuss how all identities are indeed mistaken and always entail misrecognition. From there we move on to the postcolonial structures involved in any attempt to imagine, and thus recognise, the sovereign subject as a homogenous entity capable of exhibiting both 'legal' and 'existential recognition'7 - and the inherent political consequences of such imaginations. Finally, we discuss the prospects for resisting predominant narratives and understandings of the subject as a sovereign or 'recognisable' actor in world politics as a way to suggest the possibilities involved in acknowledging misrecognition as a force of creativity and openness.

\footnotetext{
${ }^{6}$ Robert B. Pippin, Hegel on Self-Consciousness: Desire and Death in Hegel's Phenomenology of Spirit (Princeton, NJ: Princeton University Press, 2011), pp. 15, 19.

${ }^{7}$ See Zarakol (this issue).
} 
In empirical terms, we examine how the Indian state is being reimagined through Hindu nationalism and how misrecognition is at the heart of this process. We show how Hindu nationalist re-imaginings have occurred through a combination of colonial epistemes and Hindu nationalist fantasies that have transformed Hinduness, or Hindutva, into national desires of a manageable and instrumentalised past, present and future. We demonstrate how, at independence, imaginations of the Indian state were shaped by the colonial legacy of empire, while also being inflected with the fantasies and myths of Hindu nationalism, hence creating a double bind of misrecognised - and at the time redundant, even abject - imaginations. The political subjectivity of India - qua a state - is thus defined in relation to at least two contradictory imaginaries, with far-reaching implications for how we should understand India's political agency internally and vis-à-vis other states as performed through colonial and precolonial imaginings that are both privileged and resisted.

\section{Moving from relational to Lacanian psychoanalysis in search of misrecognition}

The relational turn in psychoanalysis is reflected in the influence of the 'British School' of object relations theory (especially Winnicot) and Kleinian psychoanalysis from the 1940s and 1950s; in American self-psychology in the 1960s and onwards, and not least in contemporary 
intersubjectivist theory. ${ }^{8}$ As Layton has noted, ${ }^{9}$ of importance is the acknowledgement that relational conditions promote the growth of the subject and that this is closely entwined with being recognised and affirmed. The constraints by oppressive social forces and psychic impulses on human capacity need to be overcome through more fulfilling, mutually recognised relationships. In line with object relational and intersubjectivist psychoanalysis, Honneth suggests that healthy development is dependent on truthful and lasting experience of recognition from the parent and that this can be extended to the human experience as such. ${ }^{10}$ Frosh's apt summary of Honneth's theorising reads: “"Affective recognition"”, hence 'gives rise to "legal" and "status" recognition in a triad that as it develops produces new forms of human opportunity, but if blocked evidences distortions and constraints on freedom. In particular, claims for legal and status recognition can become the fuel for social struggle and collective resistance; that is, an essentially affective condition (the demand for recognition rather than, e.g., for resources) leads to political activity'. ${ }^{11}$

Fraser's critique that Honneth thus reduces the political to the psychological (making all politics a matter of identity struggle) and McNay's concern that the subject loses its sociality through being postulated as an entity that is self-constituted prior to the operations of social forces, ${ }^{12}$

\footnotetext{
${ }^{8}$ Stephen Frosh, 'Psychoanalysis as political psychology', in Paul Nesbitt-Larking, Catarina Kinnvall and Tereza Capelos (eds), Palgrave Handbook of Global Political Psychology (Oxford: Oxford University Press, 2014), pp. 55-71. See also Jay R. Greenberg and Stephen A. Mitchell, Object Relations in Psychoanalytic Theory (Cambridge, MA: Harvard University Press, 1983); Stephen A. Mitchell and Lewis Aron, Relational Psychoanalysis: The Emergence of a Tradition (London: Routledge, 1999). There is also, of course, a 'relational turn' in IR that is relevant for the present argument insofar as it shifts attention away from substantive entities and onto processes and relations, and thereby allows for the state to be theorised as not reducible to an essence or a timeless set of core 'immutable' characteristics (for more on this, see David M. McCourt, 'Practice theory and relationalism as the new constructivism', International Studies Quarterly, 60:3 (2016), pp. 475-485). As McCourt writes, within a relational approach 'agency is [...] not an inherent feature of individuals but an effect of the differential distribution of power, knowledge, and recognition in social topographies'. McCourt (2016), p. 481.

${ }^{9}$ Lynne Layton, 'What divides the subject? Psychoanalytic reflections of subjectivity, subjection and resistance', Subjectivity, 22 (2008), pp. 60-72.

${ }^{10}$ Nancy Fraser and Axel Honneth, Redistribution or Recognition: A Political Philosophical Exchange (London: Verso, 2003).

${ }^{11}$ Frosh (2014), p. 64.

${ }^{12}$ Lois McNay, 'The trouble with recognition: subjectivity, suffering, and agency', Sociological Theory, 26:3 (2008), pp. 271-296.
} 
have all been dealt with at some length by Epstein (this issue). However, more important in this criticism - and of relational psychology in general - is that relationality tends to be reduced to promoting or preventing the growth of the subject rather than structuring the subject in the first place. This criticism shares some of its foundations with recent critiques and discussions of ontological security as a trans-historical need and the extent to which the study of ontological security opens up or closes down the question of the subject in world politics. ${ }^{13}$ Proceeding from Giddens' assumptions of subjectivity, much work on ontological security highlights the need actors have to feel as if they have stable identities, and thus being recognised. It draws attention to biographical narratives, and to routinised and home-making practices as the modes for sustaining ontological security, helping us to see how those practices shape political possibilities and outcomes. ${ }^{14}$

However, similar to Honneth's discussion of self as a relational entity, Giddens' focus on keeping a particular narrative going - an 'ongoing "story" about the self" 15 - runs the risk of ignoring structural power relations while also downplaying the multiple subjective identifications spelt out in much psychoanalysis in terms of unconscious fantasy and repressed desire and thought. Reading ontological security from Hegel's work on the negative and his conception of misrecognition makes us realise that the search for ontological security, although a powerful story that continues to play a crucial part in the narratives that people and groups

\footnotetext{
${ }^{13}$ See, for example, Christopher Browning and Pertii Joenneimi, 'From fratricide to security community: retheorising difference in the constitution of Nordic peace', Journal of International Relations and Development, 16:4 (2013), pp. 483-513; Stuart Croft and Nick Vaughan-Williams, 'Fit for purpose? Fitting ontological security studies "into" the discipline of international relations: towards a vernacular turn', Cooperation and Conflict, 52:1 (2016), pp. 12-30; Chris Rossdale, 'Enclosing critique: the limits of ontological security', International Political Sociology, 9:4 (2015), pp. 369-386.

${ }^{14}$ See, for example, Catarina Kinnvall and Jennifer Mitzen, 'An introduction to the special issue: ontological securities in world politics', Cooperation and Conflict, 52:1 (2016), pp. 3-11; Catarina Kinnvall, 'Globalization and religious nationalism: The search for ontological security', Political Psychology, 25: 4 (2004), pp. 741-767; Brent Steele, Ontological Security in International Relations (New York: Routledge, 2008).

${ }^{15}$ Anthony Giddens, Modernity and Self-Identity: Self and Society in the Late Modern Age (Cambridge: Polity Press, 1991), p. 54.
} 
construct to make sense of themselves, is a story that can never be fulfilled. Hence, as the editors of this special issue argue, even when striving for sovereignty, it can never be achieved because such sovereignty constantly has to be counterbalanced by the other's consent.

It is here we find it relevant to turn to Lacanian and postcolonial psychoanalysis in search of an anti-foundational notion of subjectivity that goes beyond the pre-conception that survival and acknowledgement are fundamental to healthy identities. Rather than viewing the psyche as an individual space or place of knowledge, Lacan is concerned with the fantasies of truthfulness and wholeness that conceal the fractures of non-knowledge, of lack. In this, he shares with relational psychologists the doubt that any subject can be truly individual. Rather the subject is positioned in different ways in relation to modes of knowledge and being and the Lacanian distinction between the Imaginary, Symbolic and Real must be seen as different registers of experience relating in different ways to socio-political phenomena and to the prospects for radical change. ${ }^{16}$ As such, the impetus for a Lacanian approach to subjectivity is similar to Weber's insistence on the need to take both the binary logic of either/or and the pluralised logic of and/or into account when we try to establish its meanings. ${ }^{17}$ We propose that Lacan's concepts are well-suited to satisfy Weber's call on IR scholarship to explore the 'singular and plural figurations' that go into the 'mak[ing] and unmak[ing] [of] national, regional, and international communities'. ${ }^{18}$

\footnotetext{
${ }^{16}$ Frosh (2014). See Epstein for further expounding of how these registers of experience have specific relevance for the discipline of IR. Charlotte Epstein, 'Theorizing agency in Hobbes's wake: the rational actor, the Self, or the speaking subject, International Organization, 67:2 (2013), pp. 287-316 and 'Who speaks? Discourse, the subject and the study of identity in international politics', European Journal of International Relations, 17:2 (2011), pp. 327-350.

${ }^{17}$ Cynthia Weber, 'Queer intellectual curiosity as international relations method: developing queer international relations theoretical and methodological frameworks', International Studies Quarterly, 60:1 (2016), p. 19.

${ }^{18}$ Weber (2016), p. 22.
} 
These processes are theorised in Lacan's focus on 'master signifiers', or those signifiers to which a subject's identity is most intimately bound, such as nation, religion, gender and culture. The signifying process is never foreclosed, however, but is rather a world of 'empty signifiers' or 'signifiers without a significant'. ${ }^{19}$ Even though these signifiers remain allusive, Lacan argues, we are convinced that others know the meaning of them. This implies that any naming of a master signifier, such as India or the nation, only has symbolic agency through the inscriptions within a symbolic order that is itself imbued with political asymmetries. ${ }^{20}$ This symbolic order remains alien to the subject, however. It is a 'world of words' that can never escape the symbolic filter of language. It is also a world of words that creates the 'world of things'. ${ }^{21}$ As the infant is encountering her surroundings, she is born into an existing order that is alien to her, a fundamental loss, one that already holds given meanings. To develop her agency and subjectivity she has to enter into this foreign world, which she can never fully grasp. To Lacan, words can never fully express the meaning of the subject, which implies that alienation is a basic condition for the formation of subjectivity within the symbolic order. ${ }^{22}$

A Lacanian approach that remains faithful to these insights about a generic alienation at work in the formation of political subjectivity, and to the notion of the Real as elaborated below, does thereby not lend itself easily to Adler-Nissen and Tsinovoi's suggestion that international misrecognition, on the one hand, foremost (yet only potentially) arises 'as a gap' at the interface of 'domestic discourses' and 'the "mirror" of international Others' and that it, on the other hand, 'only becomes politically salient when it is publicly articulated as a specific discourse of

\footnotetext{
${ }^{19}$ Jacques Lacan, The Four Fundamental Concepts of Psycho-Analysis: Book XI, trans. Alan Sheridan (London: Hogarth, 1978).

${ }^{20}$ Jacques Lacan, The Seminar of Jacques Lacan, Book III: The Psychoses, trans. Russell Grigg (Kent: W. Norton, 2000).

${ }^{21}$ Jacques Lacan, Jacques Lacan: Écrits A Selection (London: Routledge, 1977).

${ }^{22}$ Jacques Lacan, The Seminar of Jacques Lacan, Book II: The Ego in Freud's Theory and in the Technique of Psychoanalysis, 1954-1955, trans. Sylvana Tomaselli (New York: Norton, 1988).
} 
misrecognition'. ${ }^{23}$ Misrecognition is not reducible to discourse, nor to the presumably negative experience of a wanting consonance between how claims to selfhood are put forward and how these are conceived and reciprocated by others. ${ }^{24}$ Instead, misrecognition is primarily operative on the level where the very 'conditions of possibility of organized life' are at work, ${ }^{25}$ and - as our treatment of India will demonstrate - it becomes most manifest, i.e. 'the symptoms of the political world ${ }^{26}$ are most available to us, in the perpetual contestations that surround the task of imbuing the nation (the collective Self) with concrete meaning. With Hegel, this inclination could be expressed in the following terms: 'any self-relating is always also in a way provisional and a projecting outward, beyond the near immediacy of any mere self-taking', in part since 'self-consciousness cannot [...] find itself [... "inside itself". ${ }^{27}$ This is not the same, however, as arguing that the split subject, and its emplacement in the different registers of experience, makes itself manifest in 'a public discourse of misrecognition' made up of 'textual and visual representations'. ${ }^{28}$ After all, 'the political unconscious', as Rogers and Zevnik claim, 'will not emerge and eventually reveal itself', '[i]t does not fit into a progressive or linear narrative' and yet '[i]t is always and already there'. ${ }^{29}$

\footnotetext{
${ }^{23}$ Rebecca Adler-Nissen and Alexei Tsinovoi, 'International misrecognition: the politics of humour and national identity in Israel's public diplomacy', European Journal of International Relations, online first (2018), pp. 2-3, 20.

${ }^{24}$ Cf. Adler-Nissen and Tsinovoi (2018), pp. 3, 5.

25 See Epstein (2013), p. 301.

${ }^{26}$ See Juliet B. Rogers and Andreja Zevnik, 'The symptoms of the political unconscious: introduction to the special issue', Political Psychology, 38:4 (2017), p. 581.

${ }^{27}$ Pippin (2011), p. 44.

${ }^{28}$ Adler-Nissen and Tsinovoi (2018), p. 5.

${ }^{29}$ Rogers and Zevnik (2017), p. 581. Given this, it seems undesirable to abide by Adler-Nissen and Tsinovoi's limited ambition, i.e. to regard misrecognition as politically relevant only 'when it is publicly articulated as a specific discourse of misrecognition'. Adler-Nissen and Tsinovoi (2018), p. 20. This seems to tacitly assume despite their claim that 'misrecognition is inherent in any identification process' - that there are moments of 'recognition' that equal a 'stable pooling of identity'. See Julia Gallagher, 'Creating a state: a Kleinian reading of recognition in Zimbabwe’s regional relationships', European Journal of International Relations, 22:2 (2016), p. 400. This, to us, is a way too optimistic answer to Hegel's apt questions, as formulated by Pippin: [h]ow can a subject of thought and deeds that always experiences itself as beyond or more than its material states come to any resolution about who or what it actually "is"; how can it find satisfaction in the absence of any such resting place like its biological species-form?'. Robert B. Pippin, After the beautiful: Hegel and the philosophy of pictorial modernism (Chicago: The University of Chicago Press, 2014), p. 46.
} 
In comparison to Giddens' idea of reflexivity as defining the subject and to postcolonial notions of subjectivity as being constantly rewritten and performed by the powerful (a theme returned to below), Lacan's subject is always dependent on images of others in the construction of self, which implies that belief is always belief through an Other and that such belief precedes the subject's self-understanding. Hence, according to Lacan, all identities are mistaken and it is a mistake to believe that we can truly learn who we are in the gaze of others. Not even the mirror image is a 'true' representation as it is always inverted (reverses right from left), but more importantly it is always alien, a Gestalt, and thus alienating. It is hence symptomatic of Lacan's subject as being always split. This 'split subjectivity' lends itself to the decentering of a sense of self and is exacerbated by the socio-symbolic order that is already split into antagonistic forces and interests. ${ }^{30}$ The subject can accordingly never speak in words apart from the symbolic order. The use of words that belong to everyone and hold generic meaning will not be able to repeat the direct experience of being able to speak in the first place, which implies that the subject is constantly split between a desire to speak from within and the wish to become integrated into a symbolic order that pre-exists it. The 'speech is the murder of the thing', 31 meaning " "the thing" in its original, raw individualized form must be relinquished so as to be mediated by language, that is to say fitted into an existing signifier'. ${ }^{32}$ This is also what makes a cohesive self impossible - the subject is not only split but is also characterised by a constant lack - a lack of stable identity, a lack of certainty and a lack of a full sense of self.

Lacan's conception of the Real (the unconscious direct experience) ${ }^{33}$ is in line with Hegel's ideas of recognition as something that is impossible to achieve. But it is also a state of

\footnotetext{
${ }^{30}$ Lacan (2000).

${ }^{31}$ Lacan (1977).

${ }^{32}$ Epstein (2011).

${ }^{33}$ The Real can be seen as opposite to reality which is always fictional. The Real refers to meaning construction as 'the truth of our desire' and is always partial or entirely buried in our unconscious. In contrast to the Symbolic and the Imaginary, which are characterised by their social dimension (a shared experience), truth is singular to
} 
ontological insecurity, as it refers to a process in which we can never fully know either the past or the future. In contrast to the Imaginary and the Symbolic, the Real is that which escapes language and representation - it is that which avoids discursive representation. In this regard, a Lacanian conception of subjectivity differs from many poststructural or postmodern versions of self that exist in discourse only. To overcome uncertainty, or lack in Lacan's terminology, the subject engages in fantasies and imaginations. As Ruti argues: ${ }^{34}$ '[s]uch fantasies alleviate anxiety and fend off the threat of fragmentation because they enable the subject to consider himself [sic] as more united and complete than he actually is; by concealing the traumatic split or tear within the subject's being, such fantasies lend an always illusory form of consistency and meaning to his existence'. It is this idea of fantasies in response to a constant lack that opens up for the desire for recognition. 'The subject desires full representation through his/her signifiers. Yet since no signifier delivers this fullness, a signifier never satisfies desire. No signifier is ever fixed, stabilized, or incontestable. Desire slides along signification in search of full representation, but since this fullness is ultimately impossible, desire is always "desire for something else"" ${ }^{35}$ These are the fantasies of sovereignty that Markell talks about in which the imaginary of a complete self is being sought for ${ }^{36}$ It is a fantasy space in which the reflexive capabilities of self remain overshadowed by various forces - including the system of social relations, of desire and of language. As Frosh has argued 'the subject believes itself to be an active conqueror of the domain of otherness, consuming its gifts in order to strengthen itself; but it is also at the mercy of the other, dependent on it, unconsciously infiltrated and knocked

each individual. This does not imply any kind of universal truth, however, but refers to the direct experience that escapes any grasp of representation, as seen in the common inability to decide what it is we really want or desire. Lacan (1988), pp. 51-55; Alexandre Leupin, Lacan Today: Psychoanalysis, Science, Religion (New York: Other Press, 2004), pp. 47-49.

${ }^{34}$ Mari Ruti, World of Fragile Things: Psychoanalysis and the Art of Living (New York: State University of New York Press, 2008), p. 97.

${ }^{35}$ Ty Solomon, The Politics of Subjectivity in American Foreign Policy Discourses (Michigan: University of Michigan Press, 2015), p. 32.

${ }^{36}$ Patchen Markell, Bound by Recognition (Princeton, NJ: Princeton University Press, 2003). 
off course by it, tied to it by processes of desire and need, yet always fighting against this awareness', ${ }^{37}$

Hence the aim of Lacan's analysis is to unpack these fantasies, to show how they are in fact misguided and rely on an unstable ground - a belief in an ego that does not exist. Lacan's lack and the fantasies of the subject involve an identification with an outer, imaginary coherence of a united self that is then materialised through language (the symbolic order). In simplified terms, it means that the sources of our (imagined) identities exist outside of us; they are created through those images with which we identify and through the linguistic order that assigns names and terms to these images. As master signifiers, they provide the foundation for a series of identifications and relations with significant others, but they also put emphasis on those actors and structures that are able to claim correct interpretations by appealing to the insecurities prevalent in Lacan's lack.

Here, Lacan goes beyond much work in current IR to explore such unfixity in terms of 'lack' developing a theoretical model on the basis of what is lacking in human desire. In this, the intimate relation between desire and lack is fully explored as desire is stimulated by a lack that can never be fulfilled. It rather aims at reproduction by keeping us away from what Lacan terms jouissance, enjoyment, which is what desire can never reach - something total, but impossible. ${ }^{38}$ This can of course be interpreted in line with the negativism, or even nihilism, associated with Lacanian theory regarding the extent to which social change can occur if one assumes that lack is constitutive and unavoidable. ${ }^{39}$ However, Lacanian theory can also be viewed as opening up a possibility in IR theory to reason around desires for recognition as being

\footnotetext{
${ }^{37}$ Frosh (2014), p. 60.

${ }^{38}$ Jacques Lacan, The Object of Psychoanalysis, unpublished, trans. Cormac Gallagher (1966).

${ }^{39}$ See Andrew Robinson, 'The politics of lack', British Journal of Politics and International Relations, 6:2 (2004), pp. 259-269.
} 
a condition of both possibility and impossibility, of both opening up and closing down, of both monological closure ${ }^{40}$ and creativity ${ }^{41}$. It also points to how unconscious desires for recognition become institutionalised in a symbolic order that privileges the retelling of events in certain structured ways. Such a retelling of events is perhaps nowhere more evident than at times of crises, especially as these are related to traumatic events.

\section{Moving from Lacanian analysis to the postcolonial in search of misrecognition}

The focus on institutionalised unconscious desires can be related to Hegel's understanding of a system of misrecognition interpreted through postcolonial psychoanalysis. Hegel's master-slave dialectic is, as Markell notes, ${ }^{42}$ a way to open up the inner workings of colonialism. Fanon's Black Skin, White Masks clarifies how desires of recognition are linked to trauma of sorts, ${ }^{43}$ but also how such traumas need not refer to a single event or indeed to an empirical reality, but rather to 'multiple traumas, frequently analogous and repeated', ${ }^{44}$ often through fantasies. ${ }^{45}$ For Fanon, what makes a black person 'an object among other objects' is the white gaze, most vividly described in his own recount of how he was met by the fearful gaze of a white child: 'Maman, look a Negro; I'm scared!'. ${ }^{46}$ The scene describes a misrecognition of the black man, but it is here that Fanon revises crucial Freudian conceptualisations in his reference to 'neuroses of lactification' - the wish to be white - by showing how it is through the 'total identification

\footnotetext{
${ }^{40}$ Mikhail Bakhtin, The Bakhtin Reader, Pam Morris (ed) (London: Arnold, 2001).

${ }^{41}$ For a similar argument in relation to the 'creative' side of ontological insecurity, see Solomon (2015).

${ }^{42}$ Markell (2003).

${ }^{43}$ Franz Fanon, Black Skin, White Masks (New York: Grove Press, 1952).

${ }^{44}$ Freud, cited in Fanon (1952), p. 123.

${ }^{45}$ This is also a theme explored in Freud who was concerned with the way in which trauma is not a simple or single experience of events but who instead argued that traumatic events assume their force in their temporal delay. Lacan, in comparison to Freud however, is predominantly concerned with the symbolic effect of language on the mind, which infers that the human capacity for symbolisation cannot be tackled by the same methods that are used to study the body's functioning. See Lacan (2000) and Leupin (2004).

${ }^{46}$ Fanon (1952), p. 91.
} 
with the white man' ${ }^{47}$ the white gaze, that the black man begins to misrecognise himself too. The colonial environment thus creates a system of misrecognition that affects subjectivity and acts as a trigger of neurosis, characterised by racism and by epistemic, psychological and physical types of oppression. As described by Fuss: ${ }^{48}$ '[f]orced to occupy, in a white racial phantasm, the static ontological space of the timeless "primitive," the black man is disenfranchised of his very subjectivity'. But despite being mediated through unconscious processes, Fanon argues, such neuroses, or desires, are ultimately grounded in the inequalities present in the wider social structures, not in personality factors of the colonised or in the internal psychic workings of individual subjects. ${ }^{49}$

Instead, 'identification', Fuss suggests, is a kind of psychic geopolitics, 'an imperial process, a form of violent appropriation in which the Other is deposed and assimilated into the lordly domain of Self ${ }^{50}$ This, it needs to be pointed out, is not the same as claiming that there are no possible or existing alternatives to associating 'the subject of colonial modernity' with 'a particular body - male, elite and especially European "white", but merely an observation that 'the ontology of embodied subjectivity is necessarily relational' and 'that the black man's body is caught within a social comparison' marked by colonialism. ${ }^{51}$ The colonial subject is thus always 'overdetermined from without', Fanon writes. 'It is through image and fantasy - those orders that figure transgressively on the borders of history and the unconscious - that Fanon most profoundly evokes the colonial condition', 52

\footnotetext{
${ }^{47}$ Fanon (1952), p. 124.

${ }^{48}$ Quoted in Ross Truscott and Derek Hook, 'Lessons from the postcolony: Frantz Fanon, psychoanalysis and a psychology of political critique', in Nesbitt-Larking et al. (2014), p. 140.

49 See Truscott and Hook (2014)

${ }^{50}$ Diana Fuss, 'Interior colonies: Frantz Fanon and the politics of identification', Diacritics, 24:2-3 (1994), p. 23.

${ }^{51}$ Robbie Shilliam, 'A Fanonian critique of Lebow's A Cultural Theory of International Relations', Millennium: Journal of International Studies, 38:1 (2009), pp. 122, 128.

${ }^{52}$ Homi K. Bhabha, 'Introduction', in Franz Fanon, Black Skin, White Masks (London: Pluto Press, 1986), p. xxvi.
} 
What this implies for our discussion of misrecognition is a need to read misrecognition not only through the unconscious aspects of colonial and neocolonial subjectivities but also through the colonial foregrounding of psychoanalytic thinking. The misrecognition of the Black man becomes not only an imaginary mirror image of whiteness, but a precondition of specific postcolonial desires for sovereignty. This is where Partha Chatterjee's discussion of India at independence becomes interesting. ${ }^{53}$ How Indian leaders had only the western or the Soviet model of the sovereign nation to choose from, thus leaving 'our imaginations forever colonized' ${ }^{54}$ These are the fantasies of sovereignty that Gayatri Spivak is also concerned with - how the sovereign subject actually inaugurated a subject:

Some of the most radical criticism coming out of the West in the eighties was the result of an interested desire to conserve the subject of the West, or the West as Subject. The theory of pluralized "subject-effects" often provided a cover for this subject of knowledge. Although the history of Europe as Subject was narrativized by the law, political economy, and the ideology of the West, this concealed Subject pretended it had "no geo-political determinations". The much-publicized critique of the sovereign subject thus actually inaugurated a Subject. ${ }^{55}$

In her insistence on deconstruction, Spivak examines the processes through which we naturalise personal history and desire into general truth, thus dismantling the very tradition of western thought that has provided the justification for European colonialism and neo-colonialism. Opening up for an anti-foundational notion of self involves dismantling the texts, or textuality, as general writing has provided a rhetorical structure that has served to justify imperial

\footnotetext{
${ }^{53}$ Partha Chatterjee, The Nation and Its Fragments: Colonial and Postcolonial Histories (Princeton, NJ: Princeton University Press, 1993).

${ }^{54}$ Chatterjee (1993), p. 41.

${ }^{55}$ Gayatri Chakravorty Spivak, A Critique of Postcolonial Reason: Toward a History of the Vanishing Present (Cambridge, MA: Harvard University Press, 1999), p. 248.
} 
expansion. Here, the notion of 'worldling' is used by Spivak to exemplify how textuality privileges and justifies colonial expansion. 'As far as I understand it, the notion of textuality should be related to the notion of worldling of a world on a supposedly uninscribed territory. When I say this, I am thinking basically about the imperialist project which had to assume that the earth that it territorialized was in fact previously uninscribed' ${ }^{56}$

Spivak's notion of 'worlding' points to how India was, in part, inaugurated as a subject through European imaginations and how such inauguration continues to be performed in terms of Eurocentrism in and outside of European political space. ${ }^{57}$ This has political implications for the ways in which we think through the desires for recognition, and the fundamental misrecognition involved in such desires, as they continue to rest on fantasies of sovereign power upheld through hegemonic and discriminate power relations. The latter involves narratives that inscribe a hegemonic set of cultural values upon territories and populations in order to control, know and domesticate certain groups of people residing in national space. In the western desire to define the postcolonial lies the tragedy that Markell has pointed to, in which 'the pursuit of sovereign satisfaction of recognition is itself a form of misrecognition' ${ }^{58}$ Taking the subaltern seriously must hence be viewed as a fundamental challenge for a critical IR theory concerned with issues of representation, recognition and misrecognition.

To Fanon, the imagining of 'the native' as living in a state of cultural immaturity and being in constant need of improvement, mediates all social relations and is constantly revisited through

\footnotetext{
${ }^{56}$ Gayatri Chakravorty Spivak, The Post-Colonial Critic: Interviews, Strategies, Dialogues (London: Routledge, 1990), p. 1. For further elaboration on Spivak's writings, see Catarina Kinnvall, 'Gayatri Chakravorty Spivak', in Jenny Edkins and Nick Vaughan-Williams (eds), Critical Theorists and International Relations (London: Routledge, 2008), pp. 317-329.

${ }^{57}$ See also Homi K. Bhabha (ed), Nation and Narration (London: Routledge, 1990); Dipesh Chakrabarty, Provincializing Europe: Postcolonial Thought and Historical Difference (Princeton, NJ: Princeton University Press, 2007).

${ }^{58}$ Markell (2003), p. 90.
} 
colonial discourse: 'the Negro enslaved by his inferiority, the white man enslaved by his superiority alike behave in accordance with a neurotic orientation' ${ }^{59}$ Here Fanon points to how the black soul is the white man's artefact, but he also highlights how the narratives through which the subaltern is imagined are both racist and gendered. In particular, he emphasises the ways in which misrecognition is embodied, juxtaposing the free modern 'natural body' from that of the 'enslaved other'. Whiteness, Seshadri-Crooks argues, ${ }^{60}$ promises wholeness, mastery, self-completion or absolute humanity (i.e. sovereignty). It precedes seeing; the symbolic order determines what we see. Here she claims that it is the anxiety that springs from a sudden encounter with the historicity of race, with evidence of its purely cultural, symbolic origins, that engenders the perception of racial features in the other. As gendered narratives, they uncover an autonomous sovereign male subject that assumes a position of neutrality, invisibility and universalism. From a Lacanian perspective, these narratives become successful through their ability to create a fantasy space of misrecognition in response to a situation of failed identity by invoking a desire to restore the Symbolic Order - to fill the Lack - the disappointments, anger, frustration and anxiety (the ontological insecurities) experienced by the colonial masters and postcolonial elites.

\section{Recognition, misrecognition and resistance}

It is within these patterns of dominance that the desire for sovereignty is most clearly imagined as a particular form of 'authentic' ${ }^{61}$ agency; one which transforms individuals and bodies into representations and representatives of an abstract, but still illusory, entity - such as 'the nation'.

\footnotetext{
${ }^{59}$ Fanon (1986), p. xxvii.

${ }^{60}$ Kalpana Seshadri-Crooks, Desiring Whiteness: A Lacanian Analysis of Race (New York: Routledge, 2000).

${ }^{61}$ As evident throughout this article and in Lacanian theorising, it is not possible to speak of actual 'authenticity', only ways in which imaginations of the 'authentic' are posited and mobilised to fill the constitutive lack.
} 
Through this fantasy, the register of the symbolic meets the constitution of the images of the people as one and territorial integrity - a national symbolic emerging through language, culture and laws. ${ }^{62}$ In other words, the nation in particular, with its dual function of demarcating community and providing it with both foundation and purpose, stands out as the paramount vessel for fulfilling that longing for wholeness and equivalence, which in the present article is described as a desire for sovereignty. With Burgess, we take 'sovereignty as a more general rule' to be 'the name of a certain relation to the self' ${ }^{63}$ In Rogers and Zevnik's terms it could be described as a desire 'for the certainty of identity' - a desire bound up with desires for 'safety', 'leadership', etc. ${ }^{64}$ It is, in other words, a desire that seeks to infinitely, to speak with Hegel, ${ }^{65}$ assuage the 'subject's relentless drive to put itself in relation to authority'. ${ }^{66}$ Infinite since 'the self is not sovereign', 'never fully itself, never adequate to the task of being itself, of fully identifying with itself' ${ }^{67}$

This can be interpreted through those normalising narratives that frame the symbolic order inherent in the everyday and the mundane. It is also reflected in the autochthony of identity politics, attached to places within places, parts within wholes, in which the call for sovereignty requires recognition of particular group characteristics in terms of internal difference: multiculturalism or the rainbow nation, in which differences are delineated in terms of imagined wholes. ${ }^{68}$ The fantasmatic (fictional) object that Lacan speaks of - the imagination

\footnotetext{
${ }^{62}$ Brian R. Axel, The Nation's Tortured Body: Violence, Representation and the Formation of a Sikh 'Diaspora' (Durham, NC: Duke University Press, 2001).

${ }^{63}$ J. Peter Burgess, 'The real at the origin of sovereignty', Political Psychology, 38:4 (2017), p. 667.

${ }^{64}$ Rogers and Zevnik (2017), p. 582. It is important here to keep in mind what Burgess points out, i.e. that '[t]he object of desire can only appear as an unspecified, indeterminate object' and that '[t]he subject is driven, has its energy and ethos in [...] desire, but the desire seeks an elusive satisfaction'. Burgess (2017), p. 659.

${ }^{65}$ See Terry Pinkard, Does History Make Sense? Hegel on the Historical Shapes of Justice (Cambridge, MA: Harvard University Press), p. 42.

${ }^{66}$ Rogers and Zevnik (2017), p. 588.

${ }^{67}$ Burgess (2017), p. 654, emphasis added.

${ }^{68}$ Jean Comaroff and John L. Comaroff, 'Naturing the nation: aliens, apocalyses, and the postcolonial state', in Thomas Blom Hansen and Finn Stepputat (eds), Sovereign Bodies: Citizens, Migrants and States in the Postcolonial World (Princeton, NJ: Princeton University Press, 2005), pp. 120-148.
} 
of (superior/inferior) others - is crucial to such imaginations as it allows for the master, to speak with Hegel, to envisage absolute sovereignty in relation to both other masters and to the slave, but also for group cohesiveness to be the basic tenet for the fantasies of social and cultural others as homogenous wholes. Resistance to such narratives must hence be viewed in terms of bottom-up approaches allowing for subjectification and re-appropriation of alternative narratives that can resist and subvert hegemonic dominance. As Hall has argued in relation to black identity, the essence of any community is always imagined and in a process of becoming. ${ }^{69}$ It has different meanings in different contexts - it is in Hegel's terminology always misrecognised. This, as many have acknowledged before us, opens up possibilities for thinking otherwise, and here a reliance on psychoanalysis seems particularly fruitful.

Fanon's demand for a psychoanalytic explanation emerges from the perverse reflections of "civil virtue" in the alienating acts of colonial governance: the visibility of cultural "mummification" in the colonizer's avowed ambition to civilize or modernize the native which results in "archaic inert institutions [that function] under the oppressor's supervision like a caricature of formerly fertile institutions"; or the validity of violence in the very definition of the colonial social space; or the viability of the febrile, fantasmatic images of racial hatred that come to be absorbed and acted out in the wisdom of the West. $^{70}$

Challenges to naturalised narratives of superiority, inferiority and group cohesiveness arise, as Butler has pointed out, when there is 'performative contradiction'; that is, 'to exercise freedom

\footnotetext{
${ }^{69}$ Stuart Hall, 'Who needs “identity”?', in Stuart Hall and Paul Du Gay (eds), Questions of Cultural Identity (London: Lawrence and Wishart, 1996).

${ }^{70}$ Bhabha, in Fanon (1986), p. xxvii.
} 
and to assert an equality can and must move beyond their positive articulations. The contradictions must be relied upon, exposed, and worked on to move toward something new'. ${ }^{71}$

It is from this tension - both psychic and political - that a strategy of subversion emerges as a way to overcome the loss of hegemonic definitions, to repoliticise structures of domination: '[i]t is a form of power that is exercised at the very limits of identity and authority, in the mocking spirit of mask and image; it is the lesson taught by the veiled Algerian woman in the course of the Revolution as she crossed the Manichean lines to claim her liberty'. ${ }^{72}$ This means recognising the importance of engaging acts that go beyond the horizons of what appears to be possible and redefines the very contours of what is possible. ${ }^{73}$ In Lacanian terms, it constitutes a possible way out for the subject in terms of being caught between the Real and the symbolic order, thus containing a prospect for turning misrecognition into a source of creativity. ${ }^{74}$ Rather than unreflectively identifying with a dominant hegemonic narrative, Solomon argues,${ }^{75}$ the lack of an essentialist homogenising identity can actually encourage subjects to creatively engage with desires to live in new ways. An approach towards recognition that takes seriously an anti-foundational notion of self is thus able to rethink misrecognition as something existing in everyday structures, symbols and discourses which shape the subject in ways that remain unfinished, thus implying that all imaginary subjectivities have in common this incompleteness.

\footnotetext{
${ }^{71}$ Judith Butler and Gayatri Chakravorty Spivak, Who Sings the Nation-State (London: Seagull Books, 2010), p. 66.

${ }^{72}$ Bhabha, in Fanon (1986), p. xxxiv. Bhabha is here commenting on Fanon's discussion of the war in Algeria.

73 Judith Butler, Ernesto Laclau and Slavoj Zizek, Contingency, Hegemony, Universality: Contemporary Dialogues on the Left (London: Verso, 2000).

${ }^{74}$ This is consonant with Lacan's encouragement to his patients to 'cross the fantasy' or to be 'crossing the plane of identification'. Jacques Lacan, The Four Fundamental Concepts of Psychoanalysis: The Seminar of Jacques Lacan Book XI, ed. Jacques-Alain Miller, trans. Alan Sheridan (New York: W.W. Norton, 1981), p. 273.

${ }^{75}$ Solomon (2015).
} 


\section{Misrecognition and the Indian state}

\section{Independence as an act of incompletion}

To view sovereignty as hybrid, provisional and contested and the state as an always unfinished and continuous project of control and subordination seem to resonate well with the experiences of colonial and postcolonial India. Despite colonial rule at times being described as saving India from centuries of corrupt and decadent Muslim rule, there is little to indicate that sovereignty in precolonial India was anything else than segmented, overlapping and stratified. ${ }^{76}$ Even during British colonisation, the principal aim of the colonial power was to maintain stability and order (often through the use of systemic and excessive violence), ostensibly leaving the imagining of the nation to what Chatterjee has referred to as the 'inside': the family, language and community. ${ }^{77}$ Hence, the colonial state was perceived as making its presence mainly in the 'outer' and public domains, while the 'inside' was regarded as the uncolonised heart of Indian society. Such a portrayal, however, tacitly (and wrongly) implies that British colonialism was tangential and marginal vis-à-vis and, in comparison with, a more deep-seated civilizational trajectory in the region, and posits a distinction between inside and outside that is hardly tenable. It thereby fails to account for the far-reaching co-constitution of imperial and Indian considerations of sovereignty and the considerable impact of colonial undertakings on British nationalism specifically and on the nation form broadly. It is within these essentialising narratives - of a posited 'political' outside and 'cultural' inside and of an Indian civilization that remains intact through times of 'external' domination and revitalised at the end of empire - that India's search for recognition must be approached in terms of a shifting world order from the late 1940s and onwards.

\footnotetext{
${ }^{76}$ Norbert Peabody, Hindu Kingship and Polity in Precolonial India (Cambridge: Cambridge University Press, 2003); Pamela G. Price, Kingship and Political Practice in Colonial India (Cambridge: Cambridge University Press, 1996).

${ }^{77}$ Chatterjee (1993).
} 
After independence in $1947,{ }^{78}$ Indian governments sought to build a national identity on nonalignment and strategic autonomy as foundations for the Nehruvian tradition of international relations. In its pursuit of international recognition and to counter the Eurocentrism involved in the legacy of the British empire, this attempt was guided by a post-independence tendency to emphasise secular distributive and populist policies. The imagination of another nation, as Chatterjee once suggested, ${ }^{79}$ a nation freed from the many imperialisms of the past, could mainly be done through the prominence of 'Indianness' to guide policies at home and abroad. This imagination cannot be separated from the events leading up to the partition in 1947, when British India was violently divided into the two sovereign states of India and Pakistan. The rivalry between India and Pakistan, confirmed at the outset and manifest in three open wars (1947, 1965 and 1971) and one undeclared (1999) - together with multiple border skirmishes and military stand-offs - have sometimes been crudely portrayed 'in terms of a two-person, non-cooperative game where external sanctions provide the only possibility'. ${ }^{80}$ However, reading the partition through a psychoanalytical and postcolonial lens suggests that the twonation theory underlying the partition had to resort to imagined conceptions of Hindus and Muslims as not only separate communities, but communities with separate pasts, cultures and identities. For India, the main desire for sovereign agency at the time of decolonisation was propelled by and revolved around coming to terms with internal fracturing, rather than the turning of India into a regional hegemon, an international force to be reckoned with, etc. The partition violence was primarily an internal, and not an international, affair.

\footnotetext{
${ }^{78}$ India and Pakistan were established as independent states in August 1947. The immediate backdrop to this event was a hastily made decision by the British to, on the basis of the two-nation theory as propagated by the Muslim League, transfer power not to one, but two, successor states. Another major aspect of the transition from British paramountcy in the region was the coeval integration of 565 'princely states' that had subsisted as independent polities yet deprived of the possibility to engage in diplomatic relations with other states and to, without British involvement, declare war. The demise of British rule marked the end of empire as well as the culmination of the twin branches of the Indian nationalist movement's struggle, spearheaded respectively by the Congress and the Muslim League, to achieve self-determination.

${ }^{79}$ Chatterjee (1993).

${ }^{80}$ Subrata K. Mitra,'War and peace in South Asia: a revisionist view of India-Pakistan relations', Contemporary South Asia, 10:3, (2001), p. 377.
} 
The intricacies of postcolonial Indian state formation have been described by Svensson in his book on the 'production of postcolonial India and Pakistan'. ${ }^{81}$ Here, he concurs with and paraphrases Brass' argument that an 'independent India elevated the preservation of "national unity and integrity" into a prime obsession; all available methods, including force, have consistently been deployed to neutralise internal and external contestations-whether in the form of secessionist tendencies or attempts to mobilise politically on the basis of (minority) religious identity'. ${ }^{82}$ However, Svensson insists that this must be understood through the function attributed to the 'nation' and the 'national community' during the partition violence in $1947,{ }^{83}$ as these became the prioritised vessels for delineating belonging and abjection in terms of temporality, space and the future projection of Indian statehood. The imaginations involved in the postcolonial state construction were thus largely derived from the dual, concurrent yet not easily integrated experience(s) of independence and partition.

In his book, Svensson has, consequently, claimed that the transition from British rule to India gaining recognition as a sovereign state ought to be conceived of as a juncture wherein 'a foundation of authority is established in an inherently non-foundational moment' ${ }^{84}$ In other words, when we relate to the inauguration of India as a nation state, we deal with a moment that does not fully obtain its meaning or direction from past events, it is - to a considerable extent - baseless. If understood in relation to Lacan, India's independence marks the onset of a search for singularity, totality and recognition, while at the same time being a pertinent example of the

\footnotetext{
${ }^{81}$ Ted Svensson, Production of Postcolonial India and Pakistan: Meanings of Partition (London: Routledge, 2013).

${ }^{82}$ Brass (1994), in Svensson (2013), p. 3.

${ }^{83}$ The partitioned provinces of Punjab and Bengal in particular became sites of largescale migration and communal violence during the second half of 1947. Unconfirmed figures speak of more than 12 million migrants and one million dead. Sammyh S. Khan et al., 'Lessons from the past for the future: the definition and mobilisation of Hindu nationhood by the Hindu nationalist movement of India', Journal of Social and Political Psychology, 5:2 (2017), p. 478.

${ }^{84}$ Svensson (2013), p. 2. In a later part of his book, Svensson depicts India's moment of independence as an 'inbetween moment', one that allows for the question 'what orders between orders?' to arise and be addressed. Svensson (2013), p. 166.
} 
intrinsic misrecognition that is involved in any attempt at reaching closure, consummation and certitude. There is hence a need to be attentive to and address 'the relation between a fundamental void or lack and the incessant drive to overcome it'. ${ }^{85}$ However, India's independence in 1947 is not merely an example of such an incessant drive to arrive at a sense of final and complete self-recognition and self-sameness. It, in addition, points to the momentary and transient openness that marks subject formation and identification at the shift from one (symbolic) order to another. Expressed in Ruti's terms, what India in August 1947 stands as a testament to is the rare occurrence of "transcendent episodes that manage to puncture the canvas of our sociolinguistic reality', episodes wherein ' $[t]$ he integrity of both self and world becomes permeable' ${ }^{86}$

Svensson's emphasis is not on India's search for sovereign or international recognition by other states. Instead, the Indian case - in line with Lacan's view of the subject - accentuates how 'the original split is not between the One and the Other, but is strictly inherent to the One; it is the split between the One and its empty place of inscription' ${ }^{87}$ This is not meant to deprive India of a past nor does it signal a denial of continuities between the period of British imperialism and its aftermath. Rather, it puts focus on - and gives us a possible answer to - why India as a nation state remains caught in a vortex of incompletion and misrecognition. The latter both induces efforts to make the particular universal, as in the instances of Congress-propelled secular nationalism and the more chauvinist Hindu nationalist project, and to forcefully attain secure borders, contain secessionist movements and position India at the helm of regional affairs. For, as Svensson contends, 'any attempt to establish purity, to fill the gap and to reveal

\footnotetext{
${ }^{85}$ Svensson (2013), p. 25.

${ }^{86}$ Mari Ruti, The Singularity of Being: Lacan and the Immortal Within (New York: Fordham University Press, 2012), p. 27.

${ }^{87}$ Slavoj Zizek, The Parallax View (London: MIT Press, 2006), p. 38.
} 
a more authentic identity is destined to fail' ${ }^{88}$ Or, to speak with Badiou, it is never a matter of arriving at a neat disclosure of the real; we instead need to '[understand] that the gap is itself real' ${ }^{89}$ In the case of India, the 'impossible desire to be recognised as the sovereign actor that one never quite is ${ }^{90}$, is principally enacted on the domestic stage and in an inward-looking fashion. This is, after all, where India as a container and emblem of sovereign agency is most immediately and fundamentally contested. The latter is most evidently contained in the numerous challenges to India's territorial integrity, e.g. Kashmir, the Maoist insurgency, secessionist tendencies in the North-East, and in the Indian state's militarized response to such contestations.

However, in the case of India, misrecognition is not strictly the outcome of endeavours to explicitly name, decide upon and ascertain the new, it is also bound up with the obscuring and silencing of founding violence ${ }^{91}-$ a violence that is not only embodied through and represented by the atrocities that make up the partition, but also by the Constituent Assembly's work to set the parameters for citizenship, nationhood, social and political rights, etc. What the Indian case thus affords us is an instance of coeval meaning-making - in the sense of trying to reach a point of fixity - and forgetting. Whereas the former, in part, becomes manifest in competing attempts to ascribe stable meaning to Indian nationhood and citizenship, the latter - in the form of the partition - subsists as a traumatic event and as a 'regular point of reference' 92 for understanding communal violence in present-day India as well as the region's conflictual state relations..$^{93}$

\footnotetext{
${ }^{88}$ Svensson (2013), p. 149.

${ }^{89}$ Alain Badiou, The Century (Cambridge: Polity Press, 2007), p. 56.

${ }^{90}$ See Epstein's contribution to this special issue.

${ }^{91}$ Such a concealment of 'founding violence' is, we would contend, part of every attempt at speaking of statehood or nationality in singular, unified terms. What is specific about India in 1947 are the manifest, immediately tangible and observable qualities of such efforts, both as regards the violence itself and its simultaneous effacing.

92 Ravinder Kaur, Since 1947: Partition Narratives among Punjabi Migrants of Delhi (New Delhi: Oxford University Press, 2007), p. 24.

${ }^{93}$ The partition, both as a lived, felt experience of individuals and for narrations of community and state identity, confirms the duality Hutchison's sees in trauma, i.e. that even though it on the individual level often represents 'a rupture of the social fabric upon which individuals rely, traumatic events can also help to form the social
} 
These entangled dynamics, i.e. of a retroactive inscription of meaning and of its failure, point to the validity of stressing misrecognition as being at the heart of postcolonial subject formation.

It, furthermore, evinces how any act to close down the subject and to restore an earlier state of imagined coherence and unity is bound to be violent. In the specific case of India, the violence is at its most apparent in the short-lived promise of openness and undecidability that the moment of independence imparted and in the transitory immanence of India as a bundle of heterogeneity, past and present. Instead, what the official historiography has foremost, and with devastating consequences, put forward is a narrative of Indian independence in 1947 'as a return to normalcy' and of the partition, 'British rule, and even Moghul rule in some quarters' as 'equivalent to the distortion and corruption of authenticity'. 94

As such, it bears testimony to how there is an excess that evades the 'neat, unified image' of origin 'that the subject forms of itself' ${ }^{95}$. Expressed differently, India's independence as a moment of misrecognition is not equivalent to an obstruction to self-sameness that is possible to overcome; it is the structuring condition of India's impossible drive to secure sovereign agency. To reconnect with Lacan, the Real ought to be conceived of as that which avoids discursive representation and which, therefore, gives rise to a need for the subject to commit to and engage in fantasies and imagination. As a consequence, and as the case of India - with its partial remembrance and forceful closure of possible heterogeneity - indicates, the bases of our identities lie outside of us. At the same time, for a brief moment, the independence of India heightened the disjuncture between the Real and the symbolic order and, thereby, promised to

attachments needed to constitute community'. Emma Hutchison, Affective Communities in World Politics: Collective Emotions after Trauma (Cambridge: Cambridge University Press, 2016), p. 2. In the case of the partition, it is, however, a frail and unreliable basis for such an 'affective community', always revisited by the event's association with disorder, incongruence, lack of closure, etc. If Hegel was right in suggesting that 'selfknowledge is self-constituting', as we believe he was, the self-knowledge that the partition allows for is constituting a highly fractured, incomplete sense of self. See Pippin (2014), p. 41.

${ }^{94}$ Svensson (2013), p. 29.

${ }^{95}$ See Epstein (this issue). 
allow for misrecognition to act as a source of creativity. ${ }^{96}$ Nonetheless, and in line with Spivak's reasoning, any exposition on India's independence will find a naturalisation of 1947 as embedded in a neat and chiefly triumphant chronology of historical events and a desire to render the particulars of state formation in the late 1940s as general and unavoidable 'truths'.

\section{Healing the partition memory}

The misrecognition amplified by the partition moment became not only naturalised in a neat chronology of historical events, but also re-imagined in terms of past and present victimisation and battles. India, together with Pakistan, became the first British colony outside Europe to win independence, and in response to the logics of colonial empire and partition violence the leaders swore to make democracy work in a multi-religious, multilingual and multi-ethnic region that had previously never been united. Within this imagination of a united national space, two specific dimensions of the original split inherent in the partition stood out as ways of healing the sovereign lack that was viewed as having caused it. One can be found in the particular kind of secularism that became the guiding principle for the Nehruvian government, while the other took the form of non-alignment and redistributive policies.

India adopted secularism and constitutionalised religious rights as a means to overcome the religious turmoil of the pre-independence period and the partition. The particular kind of secularism was not, however, a separation of the state and religion as common in many parts of the west, but a specific interpretation of secular practices that meant a continuous involvement of the state in religious affairs - what has been described as 'sarva dharma samabhava' - 'equal respect for all religions' or 'unity in diversity'. ${ }^{97}$ Within this guiding

\footnotetext{
${ }^{96}$ See also Juliet Flower-MacCannel, 'Lacan's Imaginary: a practical guide', in Samo Tomsic and Andreja Zevnik (eds), Jacques Lacan between Psycoanalytics and Politics (London: Routledge, 2016), p. 79.

${ }^{97}$ Chris Ogden, Hindu Nationalism and the Evolution of Contemporary Indian Security (New Delhi: Oxford University Press, 2014).
} 
principle, each religion continued to be imagined as an autonomous body to which Indian national leaders claimed secular credentials by visiting places of worship of all religious denominations with equal demonstration of piety and the broadcast media allotting equal time to the different religions. The only way to counter colonial cultural hegemonisation was thus through religious particularism, in which Hinduism and Islam were conceived of as especially significant. ${ }^{98}$ The nation as a master signifier thus came to be associated with this imagined, but partial wholeness. This specific notion of secularism has played an important part for Hindutva ${ }^{99}$ politics and for transforming the term 'Hindu' into an imagined wholeness - a trump-card identity that overrides all other identifications and desires.

The non-alignment program, closely linked to strategic autonomy and to the Nehruvian concept of social redistribution and populist polices, became another dimension of the desire to heal the partition at home and abroad. This approach encompassed specific policies of self-reliance, ahimsa (non-violence), together with an emphasis upon peace, harmony, cooperation and development, whereby all countries should be treated equally regardless of status and position. However, the colonial past also implied an anxious distrust of outside forces together with a deep-seated belief that India was destined for great power status rooted in an imagined understanding of earlier Indian empires. ${ }^{100}$ Similar to how secularism has enforced ideas of 'authentic' religious bodies, this rooting in a grandiose fantasy space of the past came to be envisioned not only in relation to perceived outside forces, but also in regard to those on the imagined inside who lay claim to separate identities, such as sub-national and ethnic attempts to challenge the idea of a strong, integral and totalising nation-state. Roy and Kumar Singh describe the application of extraordinary measures in certain parts of India as generating a

\footnotetext{
${ }^{98}$ K. N. Panikkar, Communal Threat, Secular Challenge (New Delhi: Earthworm Books, 1997).

${ }^{99}$ The term was used in V.D. Savarkar's work Hindutva: Who is a Hindu? (1923), where he argued that the Aryans who settled in India at the beginning of history constituted a nation now embodied in the Hindus.

100 Ogden (2014).
} 
'regime of impunity [...] through a process of delay, deferral and denial of justice by the state'. ${ }^{101}$ Taken together, the activities carried out in the name of the Indian state in regions where its monopoly of violence and its intactness as a nation-state are challenged have brought about entrenched grievances and far-reaching denigration of human rights, which tend to prolong, rather than end, these conflicts. ${ }^{102}$

Using postcolonial analysis, it would not be erroneous to talk about internal colonisation in such instances, within which nationalist practices act as privileging structures for domestic governance and control. In all instances where India is engaged in challenges to its territorial hold and presence, we can - as described above - see how a certain 'cartographic anxiety' informs the imaginations of the Indian state and state behaviour, ${ }^{103}$ which results in an unrealised yearning for cohesive identity. ${ }^{104}$ Hence the narrative of India as the world's largest democracy is challenged by its history of violent imposition of rule, which has often led to the interruption and hollowing out of democratic practices, and of its incapacity to rule in certain parts of its territory. ${ }^{105}$ This narrative provides further evidence of how the postcolonial is reimagined through nationalist policies in which the internal other is often dealt with as if it was external - where the external becomes the signifier through which the subject of India can gain full representation. However, since this fullness is ultimately impossible, desire is always

\footnotetext{
${ }^{101}$ Anupama Roy and Ujjwal Kumar Singh, 'The masculinist security state and anti-terror law regimes in India', Asian Studies Review, 39:2 (2015), p. 321.

${ }^{102}$ Sandra Pogodda and Daniela Huber, 'India's peacebuilding between rights and needs: transformation of local conflict spheres in Bihar, North-East India and Jammu and Kashmir?', International Peacekeeping, 21:4 (2014), pp. 447-448.

${ }^{103}$ Sankaran Krishna, 'Cartographic anxiety: mapping the body politic in India', in Michael J. Shapiro and Hayward R. Alker (eds), Challenging Boundaries: Global Flows, Territorial Identities (Minneapolis: University of Minnesota Press, 1996), pp. 194-95.

${ }^{104}$ Pratab Bhanu Mehta, 'Still under Nehru's shadow? The absence of foreign policy frameworks in India', India Review, 8:3 (2009), p. 216.

${ }^{105}$ Amrita Narlikar, 'Is India a responsible great power?', Third World Quarterly, $32: 9$ (2011), pp. 1607-1621.
} 
for something else, ${ }^{106}$ and in the case of India, it has ultimately become a desire for a 'lost' Hindu identity.

\section{Hindutva and the articulation of closed imaginations}

During the last three decades, and especially since the Bharatiya Janata Party (BJP) and its Hindu nationalist government came into power in 2014, Nehruvian egalitarian and identitybased concerns have been downplayed in favour of a foreign policy bureaucracy driven by economic growth and the preservation of national security. Such policy shifts may well reflect more proactive attempts of the Indian government to increase India's international presence and prestige, but they also bring together a politics of imagination, ontological insecurity and social mobilisation that generate violence and fear among India's minorities at the same time as the myth of the tolerant Hindu goes unchallenged. ${ }^{107}$ For the BJP, 'economic prosperity, a strong state, and an authentic and unequivocal cultural and national identity... [were] the necessary ingredients for realizing the promise of recognition in global modernity'. ${ }^{108}$ Being a global power has thus become equated not only with having a global economic growth policy, but also with the success of cultural and religious identity writ large. Here the imagination of the Indian state as a Hindu body is at the core of a totalising process of identification. The Hindu nationalist movement, and Hindutva ideology, claim to represent a pre-existing nation that was lost through outside invasions and domestic discontent. To fulfil the lack, Hindu nationalists have produced a nationalist discourse 'according to which the BJP view India as having been

\footnotetext{
${ }^{106}$ Here, we draw on Lacan's theorising, but even in Hegel we find the view that 'the subject is [...] nonidentical with his [sic] own desires - that is, he is not fully absorbed into his desires - and, as nonidentical with those desires, he is the "other" to himself (in that he is now the other "thing" that raises the questions of what standards he, as an embodied agent should follow)'. Terry Pinkard, Hegel's Naturalism: Mind, Nature, and the Final Ends of Life (Oxford: Oxford University Press, 2012), p. 59.

${ }^{107}$ Dibyesh Anand, Hindu Nationalism in India and the Politics of Fear (London: Palgrave, 2011).

${ }^{108}$ Ian McDonald, 'Hindu nationalism, cultural spaces, and bodily practices in India', American Behavioral Scientist, 46:11 (2003), p. 1565.
} 
under siege in the face of the enemy within, the Muslims who live in India, and the enemy without, Muslims who live in Pakistan and Bangladesh'. ${ }^{109}$

Narendra Modi, the current Prime Minster, has been able to utilise such ontological insecurities by promising to 'restore "Indian pride", and 'bring order to the chaos of modern India'. ${ }^{110}$ In this, he is portrayed as someone who understands the concerns of the frustrated lower middle classes (because of his 'humble' background): “I understand you because I am from among you," Modi told a rally in Gujarat with some justification'. ${ }^{111}$ However, Modi's particular kind of emotional governance is also rooted in resentment and anger directed towards the local political elite, alien ideologies (secularism, democracy and communism), westernisation of society or degenerate foreign ideas, as well as towards changed gender roles. ${ }^{112}$ Here the 'Indian' notion of secularism, as described above, has played an important part for Hindutva politics, as Hindu nationalists see the Congress version as a 'pseudo-secularism' that has eaten into the vitals of the Indian 'nation' by pampering religious (and other) minorities, rather than being fair to the Hindu majority - thus stifling 'memories of the Hindu view of good life'. 113 These memories are reimagined in terms of an enduring Hindu family, being silenced during Mughal rule, by the colonial empire and throughout the post-independence phase of Congress domination. Those who fall outside of and contest this idea of the majority family of Hindus become the fantasmatic objects of imagination, and are viewed as vilified 'foreigners', as representatives of civilizations not originating from Indian soil, or as imperfect patriots who prevent proper Hindus from their entitled enjoyment (jouissance) - and are thus a threat to the

\footnotetext{
${ }^{109}$ Ogden (2014), p. 94.

${ }^{110}$ Jason Burke, 'The Indian election and the lessons the west can take from Narendra Modi's popularity', The Guardian (10 May 2014), available at: https://www.theguardian.com/commentisfree/2014/may/10/indianelections-narendra-modi-bjp-western-policy.

111 Burke (2014).

112 Anand (2011).

${ }^{113}$ Javeed Alam, India: Living with Modernity (Delhi: Oxford University Press, 1999), p. 200.
} 
Hindu Rashtra (the Hindu nation). Hindu nationalism, by clearly identifying and projecting unwanted traits of the self onto the other, has been and continues to be successful in its attempts to build majoritarian religious nationalism, a trend exacerbated in recent years. ${ }^{114}$

In searching for recognition of the Hindu Rashtra, Hindu nationalists call for an awakening of the Hindu mind, body and body politic, ${ }^{115}$ by reaching back to the founders of Hindutva, V.D. Savarkar and M.S. Golwalkar, and their insistence that it rested on the pillars of geographical unity, racial features, religion, language and a common culture. ${ }^{116}$ According to Golwalkar, the racial factor was by far the most important and the Muslim minority posed the most severe threat by being a 'foreign body' lodged into the Hindu society, thus undermining the Hindu nation. ${ }^{117}$ In the past, the Rashtriya Swayamsevak Sangh (RSS - the Association of National Volunteers $)^{118}$ has idolised fascists, such as Hitler and Mussolini, and admired the way Nazism quickly built an economically stable state under the banner of patriotism. This heritage is not forgotten and Hindutva derives its meaning from a negation of minority Others, their allies (i.e. the communists, secularists and westernised elite) and their claims on the Hindu motherland. As the Hindu nation does not exist as a conscious corporate body, Hindu nationalists have had to create one which, they argue, is merely a re-representation of the pre-existing nation before it was colonised by Muslim and colonial forces. This historical 'logic' makes demands for the re-enactment of medieval politics seem 'natural'. Sacred places associated with the Mughal Empire, are seen as evidence of Hindu subjection, which makes their destruction a necessary

\footnotetext{
${ }^{114}$ Katharine Adeney, 'A move to majoritarian nationalism? Challenges of representation in South Asia', Representation, 51:1 (2015), pp. 7-21. See also Catarina Kinnvall, Globalization and Religious Nationalism in India: The search for ontological security (London: Routledge, 2006).

115 Anand (2011).

116 See Khan et al. (2017).

${ }^{117}$ Christophe Jaffrelot, The Hindu Nationalist Movement in India (New York: Columbia University Press, 1996).

118 The RSS is a categorically Hindu nationalist organisation, and has involved Modi since he was eight years old. It has become the vanguard of Hindu nationalism and has infiltrated almost every institution in India - including education, the judiciary, democratic ministries and more. RSS is rewriting history textbooks and creating propagandist training camps to inculcate children with their cause.
} 
part of the liberation movement of the Hindus and a strategy to deny creativity to the Muslims. ${ }^{119}$ By emphasising the desire for wholeness, inclusion and certainty, Hindu nationalists have hence been successful in fulfilling the lack through the imagination of a strong masculine state that can restore ontological security. However, the Hindu Rashtra remains allusive. As Soler puts it, ${ }^{120}$ 'the object of fantasy has a twofold status: [i]t is the object that is lacking in the subject, and the object that fills the lack in the subject'. The imaginary promise can only be supported if the object - in our case, the Hindu Rashtra - is seen as missing. ${ }^{121}$

The image of Modi as the founder of a 'new India', as a man of progress, development and anticorruption market-oriented policies, represents both the male Hindu warrior and the saviour of 'Mother India'. ${ }^{122}$ Externally this new India will not be pushed around on the global stage, while internally it will be protected from the 'pseudo-secularism' espoused by the Congress Party and from the appeasement of minority groups. In this regard, Modi provides a cohesive narrative to a masculine state that is able to assert itself both internally and externally. His open rejection of the English-speaking elite in India becomes a way to improve Hindu pride in the light of Western dominance and resentment toward the upper classes. But this masculinist state does not only exert itself upwards and outwards, but also downwards towards the most marginalised groups in the Indian society, Dalit and Muslim women. The role of gender has been crucial to this masculinist sovereign state as it aims to protect Mother India from internal and external threats. Narrating 'the nation as Mother' - a common theme following criticism against Indian

\footnotetext{
${ }^{119}$ Amalendu Misra, 'Hindu nationalism and Muslim minority rights in India', International Journal on Minority Rights 7 (2000), pp. 1-18; Neeladri Bhattacharya, 'Myth, history and the politics of Ramjanmabhumi', in Sarvepalli Gopal ed. Anatomy of Confrontation: Ayodhya and the Rise of Communal Politics in India (London, Zed Books, 1991).

${ }^{120}$ Colette Soler, 'Hysteria and obsession', in Richard Feldstein, Bruce Fink and Maire Jaanus (eds) Reading Seminars I and II: Lacan's Return to Freud (Albany: Suny Press, 1996), p. 267.

${ }^{121}$ Yannis Stavrakakis, Lacan and the Political (London: Routledge, 1999).

${ }^{122}$ Amrit Wilson, 'Gender violence, Narendra Modi and the Indian election', Open Democracy Net (2013), available at: https://www.opendemocracy.net/5050/amrit-wilson/gender-violence-narendra-modi-and-indianelections.
} 
politicians for failing to protect Indian women after the infamous rape case in 2012 - has been an important source of 'authenticity' for Hindu nationalists. ${ }^{123}$ In this narrative, the female is connected to ideas about the birth of the nation, the real Bharat (India), a female that should be freed from external onslaughts by external others (e.g. Muslim, Christian or even Western others).

The notion of a Hindu state is believed to conform to and protect what is thought to be India's feminine core - thus disregarding the multitude of internal voices not currently included in this master narrative. At the same time, it is an attempt to masculinise Hindu society, in order to go beyond the perceived emasculation of the Hindu body under Muslim and colonial rule. This reproductive and fertile body constitutes Hindutva's collective fantasy 'of a resurgent Hindu nation', which 'embodies violence, pride and a strong sense of affirmation' ${ }^{124}$ Such desire for recognition confirms Zizek's claim that fantasy (and the fantasmatic Other) sustains a sense of reality. ${ }^{125}$ This 'constant presence of [an] idea of a lost past', as Stavrakakis has argued, ${ }^{126}$ 'is not', however, 'revealing anything about the true nature of such a state: it is a retroactive projection conditioned by the intervention of symbolic lack'.

\footnotetext{
${ }^{123}$ Tanika Sarkar, 'The gender predicament of the Hindu Right', in K.N. Panikkar (ed), The Concerned Indian's Guide to Communalism (New Delhi: Penguin Books, 1999), pp. 131-159. On the gendered dimension of Hindu nationalism, see also Catarina Kinnvall, 'Feeling ontologically (in)secure: states, traumas and the governing of gendered space', Cooperation and Conflict, 52:1 (2017), pp. 90-108.

${ }^{124}$ Anand (2011), p. 98.

${ }^{125}$ Slavoj Zizek, The Sublime Object of Ideology (London: Verso, 1989).

${ }^{126}$ Stavrakakis (1999), p. 52.
} 


\section{Conclusion}

In the case of India, we find that the desire for sovereign agency and international recognition has been trapped in a double bind of misrecognition. It has been misrecognised both in terms of a continuing homogenous reading of empire (Mughal as well as British), further propounded and fuelled by the Hindu nationalist movement, and the desire to heal the Hindu Self, and by extension the Indian nation, through the fantasmatic other. This dual and mutually reinforcing misrecognition signifies the structuring postcolonial condition of India's impossible drive to attain and secure sovereign agency, testified through attempts to posit a mythical past as a ground for self-sameness and wholeness as well as through efforts to reinvent the present on the basis of Hindutva-spawned imaginings and projections of coherent and distinctive others.

The impossibility of securing an Indian sovereign agency that is marked by self-unity and completion can only be understood if the symbolic order, in which the imagination of India is made possible and confined, is taken into consideration. Naming and defining the master signifiers in terms of 'nation' and 'religion', or, more precisely, India and Hindutva in this case, reflect the subject's desire and related drive to express its distinctiveness in accordance with and as integrated into a symbolic order that pre-exists it, which - as discussed in the theoretical sections of this article - creates a split subject unable to reconcile its manifest characteristic and that which eludes discursive representation. The misrecognition inherent in the attempted fulfilling of this desire points to a lack at the heart of desire, that can only be attended to and partly filled through fantasies and imaginations - in present-day India represented by Hindutva as both a collective fantasy and a fantasy about a collective Self. 
The case of India hence substantiates two crucial points that are of relevance to the study of state formation and international recognition in IR. The overpowering of the impossible desire for the Real and for fully achieved self-comprehension — as exemplified above through, first, the Nehruvian version of postcolonial state building and, thereafter, the Hindu nationalist movement's reimagining of the Indian nation - compels us to further explore what Lacan has to say about how the unconscious and the Real impact on subject-formation, and thus on the entities that are conceived of as the composite parts of the international system as well as the ways in which sovereignty is both seen to drive and allow for agency. Put in Burgess' words, '[b]y understanding sovereignty as supported by the Lacanian Real, we can better understand both the forces that drive it to self-preservation and the insecurities that make its survival and longevity powerful hindrances to its dissolution'. ${ }^{127}$ To this it is necessary to add that a Lacanian-inspired approach to IR allows for a dynamic view of resistance and change, and it combines well with a conception of ontological insecurity as not solely a state of paralysis, but an important driving force for defiance, opposition and of thinking otherwise.

Finally, to reconnect with the introduction and the overall concerns of the special issue, the present article has substantiated and given additional weight to the claim that acts of recognition unavoidably rest on and induce misrecognition. It has, moreover, demonstrated how even totalising and naturalised efforts to speak in terms of 'authentic' communities and sovereign agency harbours unfulfilled desires of projected pasts and imaginary futures. Hence, to conclude, the article has - in concordance with what the entire special issue attends to shown how sovereign agency is best understood as a 'practical achievement' rather than an embodied subjectivity and as 'inherently social'. The latter, to our mind, gives reason to assume that there is hope for a future envisioning of India that is neither consonant with set ideas about

\footnotetext{
${ }^{127}$ Burgess (2017), p. 653.
} 
an enduring 'colonial modernity' nor structured by nationalist narratives of superiority and inferiority. 